\title{
Interactive comment on "First evaluation of the damage related to alluvial events in torrential catchments of Campania (southern Italy), based on a historical database" by C . Vennari et al.
}

\section{Anonymous Referee \#1}

Received and published: 10 February 2016

The paper "First evaluation of the damage related to alluvial events in torrential catchments of Campania (southern Italy), based on a historical database" shows a major problem: it is not clear what the studied object is. It probably depends on a mistake deriving from the word ALLUVIAL (included in the title). This is the incorrect translation of an Italian word (alluvionale) used to indicate something that is not what the word means in English.

Then, throughout the entire paper a series of words [alluvial events, events/phenomena, hydrogeological events (floods and landslides), climatically triggered events, debris flows...) are used without supplying a literature definition or at least a definition proposed by the Authors. This results in a big confusion.

Full screen / Esc

Printer-friendly version

Discussion paper 
1. Quoted literature is not related to the topic of the research. In the State of the art, the Authors quoted papers about landslides triggered by rainfall or morphometric analyses but these subjects are not the focus of the paper. They also quoted some articles on the study area but without an explanation (R91: "Other authors have performed sub-regional or regional studies in Campania on landslides and floods "). I suggest to completely reviewing the literature, trying to quote recent papers related to both the topic and the specific section of the paper. They should quote articles for a specific feature (described in the text), not merely to put in the reference list. Finally, references list should simply include the papers really quoted in the article.

2. The Authors use the adjectives historical documents/old documents without definitions or references. Both old and historical simply tell us the age of the documents, and then the reader cannot understand what kind of documents the Authors are talking about. Moreover, throughout the paper the Authors say that they performed an historical research but I did not found in the paper explanations about this research (sources, methodology etc.), and in the conclusions, they said they used existing literature, in the sense of scientifically papers of people who truly carried out historical research. Maybe this should be clarified, by saying what the Authors really did.

3. The Author do not explain neither the reason nor the criteria of data gathering. They collected a series of elements ("Particular attention has been given in the catalogue to damage to people and infrastructures") but they do not explain neither why nor to do what.

4. The data analysis section do not address any specific question but simply describe some characteristics of the data.

Full screen / Esc

Printer-friendly version

Discussion paper

Please also note the supplement to this comment:

http://www.nat-hazards-earth-syst-sci-discuss.net/nhess-2015-355/nhess-2015-355-

Interactive

comment 
RC1-supplement.pdf

Interactive comment on Nat. Hazards Earth Syst. Sci. Discuss., doi:10.5194/nhess-2015-355, 2016.

Interactive

comment 